\title{
MICROPROPAGATION OF PLANTAGO CAMTSCHATICA LINK
}

\author{
EMILIA ANDRZEJEWSKA-GOLEC, JOANNA MAKOWCZYŃSKA \\ Department of Biology and Pharmaceutical Botany \\ Medical University of Łódź \\ Muszyńskiego 1, 90-151 Łódź, Poland \\ e-mail: e.andrzejewska@wp.pl
}

(Received: January 14, 2008. Accepted: June 18, 2008)

\begin{abstract}
The Far East medicinal plant - Plantago camtschatica was propagated in vitro from tips of shoots (obtained in vitro) and from different explants of 4-week-old seedlings: seedling tips, hypocotyls, cotyledons, roots, first leaves. To our knowledge there is no information in literature about in vitro culture of this plantain. MS basal medium, supplemented with $0.6 \mu \mathrm{M}$ IAA in combination with various cytokinins (BA, KIN, ZEA), was used. After 6 weeks of culture, micropropagation rate (MR) - mean number of buds and shoots per explant - was calculated. Our study proved that $P$. camtschatica species was amenable to propagation in vitro from different kinds of explants. However, multiplication by adventitious shoot regeneration from hypocotyl explants was found to be the most suitable method for the propagation of this plant. Adventitious shoots could root without stimulation what allows to omit the stage of rooting. The plants obtained as a result of micropropagation were not phenotypically changed.
\end{abstract}

KEY WORDS: culture in vitro, Kamchatic plantain, organogenesis, Plantaginaceae, root regeneration.

\section{INTRODUCTION}

Kamchatic plantain - Plantago camtschatica Link, syn. $P$. depressa Wild. subsp. camtschatica (Cham. ex Link) Pilg. is one of the East Asian species belonging to the Plantaginaceae family. It is a perennial herb growing on slopes and sand hills near the sea in Japan, Korea, Sakhalin, Kuriles, Kamchatka, Commandor Islands and in the regions of Ussuri and Amur (Pilger 1937; Yamazaki 1993; Lee 1996). In the Far East it is a medicinal plant. The phytochemical studies have shown that this plant contains several interesting secondary metabolites, mostly iridoid glucosides: aucubin, geniposidic acid, majoroside and others, phenylethanoid glucoside: verbascoside, isoverbascoside, orobanchoside and others, also sorbitol (Ying et al. 1993; Nishibe et al. 1995; Rønsted et al. 2003).

To our knowledge there have been so far no reports on in vitro culture of Plantago camtschatica. However, some other species of the genus Plantago were studied in culture in vitro: P. afra L. (Sarihan et al. 2005), P. asiatica L. (Tu

\section{Abbreviations}

BA - 6-bezyladenine; 2,4-D - 2,4-dichlorophenoxyacetic acid; $\mathrm{GA}_{3}-$ gibberellic acid; IAA - indole-3-acetic acid; IBA - indole-3-butyric acid; KIN - kinetin; MS - Murashige and Skoog basal medium; MR - micropropagation rate; NAA - $\alpha$-naphtaleneacetic acid; TDZ - thidiazuron; ZEA - zeatin
1996; Makowczyńska and Andrzejewska-Golec 2003; Makowczyńska 2006; Makowczyńska et al. 2008); P. lanceolata L. (Fons et al. 1999; Budzianowska et al. 2004; Khawar et al. 2005), P. major L. (Brimer 1988; Mederos et al. 1997/1998); P. maritima L. (Chang and Locy 1996; Makowczyńska and Andrzejewska-Golec 2007); P. media L. (Kunvári et al. 1999); P. ovata Forsk. (Wakhlu and Barna 1989; Barot et al. 1994; Pramanik et al. 1995; 1996; Chowdhury et al. 1996).

\section{MATERIAL AND METHODS}

\section{Explant sources}

- 4-week-old Plantago camtschatica seedlings from seeds provided by the Botanical Garden of Martin Luther Universität Halle. Seeds were surface-sterilized by immersion in $2.0 \%$ sodium hypochlorite for $10 \mathrm{~min}$., then rinsed 3 times in sterile water and germinated (MS enriched with $0.9 \mu \mathrm{M}$ KIN and $2.9 \mu \mathrm{M} \mathrm{GA}_{3}$ ), as it was previously described for seeds of $P$. asiatica (Makowczyńska and Andrzejewska-Golec 2003)

- shoots derived from the in vitro culture

\section{Kind of explants}

- from seedlings: tips (approximately $0.5 \mathrm{~cm}$ long), hypocotyls (approximately $0.5-1.0 \mathrm{~cm}$ long), roots (approxi- 
mately $1 \mathrm{~cm}$ long), cotyledons (cultured whole), first leaves (cultured whole)

- from shoots: tips (approximately $0.5 \mathrm{~cm}$ long)

\section{Conditions of in vitro culture}

Conditions of the in vitro culture were the same as they have been used by us successfully for the micropropagation of the other Far East taxon - Asiatic plantain: MS medium solidified with $0.7 \%$ agar, $\mathrm{pH}$ adjusted to 5.6-5.9; $26 \pm 2^{\circ} \mathrm{C}$; light $40 \mu \mathrm{M} / \mathrm{m}^{2} \mathrm{~s}$, humidity $80-90 \%$ (Makowczyńska and Andrzejewska-Golec 2003).

The cultures were continued in a growth cabinet for 6 weeks.

\section{Growth regulators used in experiments}

for micropropagation

- auxin: 0.6 uM IAA,

- cytokinins: $2.2,4.4$ or $8.9 \mu \mathrm{M} \mathrm{BA}$ - for shoots formated from tips,

$-8,9 \mu \mathrm{M}$ BA, $9.3 \mu \mathrm{M}$ KIN or 9.1 $\mu \mathrm{M}$ ZEA - for shoot regeneration through organogenesis on hypocotyls, cotyledons, roots and first leaves.

\section{Rooting of shoots}

MS alone or MS in combination with auxins: 0.6 or 2.8 $\mu \mathrm{M}$ IAA; 0.5 or $2.5 \mu \mathrm{M}$ IBA; 0.5 or $2.7 \mu \mathrm{M}$ NAA were used.

Multiplication rate (MR) was evaluated as the mean number of buds and shoots on one explant at the end of the multiplication cycle (6 weeks).

Acclimatisation was conducted in flower pots for two months.

\section{RESULTS AND DISCUSSION}

\section{Shoot formation from seedling tips (Table 1)}

Micropropagation of the plants through culture shoot-tips is the utilisation of meristem which are already present in explants. This method is commonly employed in in vitro cultures of decorative and therapeutic plants. This method has been described also for few medicinal plants of the ge- nus Plantago. Our study is the first publication of $P$. camtschatica propagation by shoot-tips method. It was appeared to be amenable to propagation in vitro of Kamchatic plantain, but this method is less productive than other methods used in our work. The greatest MR obtained by us for seedling tips of $P$. camtschatica was only $3.7 \pm 0.7$ for MS containing $0.6 \mu \mathrm{M}$ IAA and $4.4 \mu \mathrm{M}$ BA. In our earlier study also in the case of seedling tips for the other Far East taxon of genus Plantago $-P$. asiatica $-\mathrm{MR}$ was $5.18 \pm 0.58$ for the same conditions of in vitro culture as in the present study for $P$. camtschatica (Makowczyńska and Andrzejewska-Golec 2003). Pramanik et al. (1995) obtained the best multiplication effect using seedling tips of $P$. ovata with MS medium enriched with the same growth regulators but in higher concentrations (1.1 $\mu \mathrm{M}$ IAA and $22.2 \mu \mathrm{M}$ BA).

In the base of $90-100 \%$ seedling tips the roots were grown.

\section{Shoot formation on tips of shoots derived from in vitro culture (Table 2)}

A better effect of $P$. camtschatica shoot formation was obtained by us for the culture of tips of shoots derived from in vitro culture than for seedling tips. MR was then 7.2 for MS with $0.6 \mu \mathrm{M}$ IAA and $8.9 \mu \mathrm{M}$ BAP

Shoot regeneration from hypocotyls, cotyledons, roots and first leaves (Table 3, Figs 1, 2 and 5)

Different cytokinins (BA, KIN, ZEA) with $0.6 \mu \mathrm{M}$ IAA were tested for their effect on shoot regeneration from various explants of Kamchatic plantain. In the case of each cytokinin the most shoots were regenerated on hypocotyl explants. MR (shoots and buds /explant) about 13 for BA and ZEA, and about 9 for KIN was obtained. Regeneration from root explants was high only when ZEA was applied. A very high multiplication rate in the case of hypocotyl explants from some species of the genus Plantago was obtained by some authors, and so: for species $P$. lanceolata 68.5 shoots per explant (MS + $0.45 \mu \mathrm{M}$ TDZ + 0.09 $\mu \mathrm{M}$ IBA) by Khawar et al. (2005), and for P. afra -23.17 shoot per explant (MS medium + 0.91 $\mu \mathrm{M}$ TDZ and 0.98 $\mu \mathrm{M}$ IBA) by Sarihan et al. (2005). In our experiments with

TABLE 1. Effect of various concentration of cytokinin BA and $0.6 \mu \mathrm{M}$ IAA added to MS on shoot micropropagation from seedling tips of Plantago camtschatica.

\begin{tabular}{cccc}
\hline $\begin{array}{c}\text { BA } \\
(\mu \mathrm{M})\end{array}$ & $\begin{array}{c}\text { MR of buds and shoots } \\
\pm \mathrm{SE}\end{array}$ & $\begin{array}{c}\text { MR of shoots } \\
\pm \mathrm{SE}\end{array}$ & $\begin{array}{c}\text { MR of normal shoots } \\
\pm \mathrm{SE}\end{array}$ \\
\hline 2.2 & $2.6 \pm 0.6$ & $1.9 \pm 0.4$ & $1.7 \pm 0.4$ \\
4.4 & $3.7 \pm 0.7$ & $3.6 \pm 0.8$ & $3.2 \pm 0.7$ \\
8.9 & $2.4 \pm 0.4$ & $1.9 \pm 0.3$ & $1.9 \pm 0.3$ \\
\hline
\end{tabular}

$\mathrm{SE}$ - standard error of the mean

For each treatment about 10-11 explants were used.

TABLE 2. Effect of various concentration of the cytokinin BA and $0.6 \mu \mathrm{M}$ IAA added to MS on shoot micropropagation from shoot tips of Plantago camtschatica.

\begin{tabular}{cccc}
\hline $\begin{array}{c}\text { BA } \\
(\mu \mathrm{M})\end{array}$ & $\begin{array}{c}\text { MR of buds and shoots } \\
\pm \mathrm{SE}\end{array}$ & $\begin{array}{c}\text { MR of shoots } \\
\pm \mathrm{SE}\end{array}$ & $\begin{array}{c}\text { MR of normal shoots } \\
\pm \mathrm{SE}\end{array}$ \\
\hline 2.2 & $4.2 \pm 0.7$ & $2.4 \pm 0.4$ & $2.4 \pm 0.4$ \\
4.4 & $4.9 \pm 1.0$ & $3.6 \pm 0.8$ & $3.5 \pm 0.6$ \\
8.9 & $7.2 \pm 0.9$ & $4.8 \pm 0.8$ & $4.8 \pm 0.8$ \\
\hline
\end{tabular}

SE - standard error of the mean

For each treatment about 17-22 explants were used. 

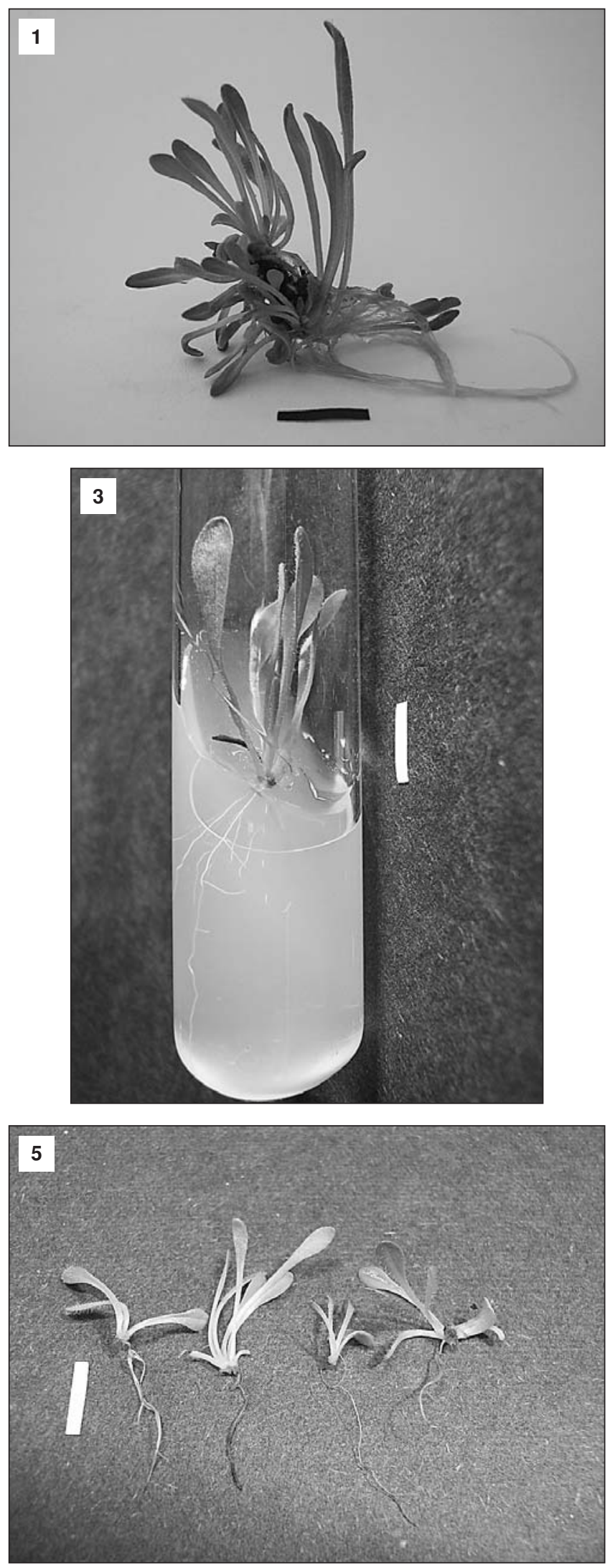

Figs 1-5. Plantago camtschatica Link in culture in vitro.

Fig. 1. Direct organogenesis on the disected fragment of hypocotyl. MS + 0.6 $\mu$ M IAA + 9.1 $\mu$ M ZEA. Fig. 2. Direct organogenesis on the cotyledo. MS + $0.6 \mathrm{uM} \mathrm{IAA}+9.1 \mu \mathrm{M}$ ZEA. Fig. 3. Rooted shoots on the MS after 4-week-old culture. Fig. 4. Rooted shoots on the MS supplemented with $0.5 \mu \mathrm{MM}$ NAA after 4-week-old culture. Fig. 5. Rooting shoots after 6-week micropropagation on leaf. MS + 0.6 $\mu$ M IAA + $9.3 \mu \mathrm{M}$ KIN. Bar $1 \mathrm{~cm}$.

Fig. 6. Plantago camtschatica Link after two-month pot growth. Bar $1 \mathrm{~cm}$.

$P$. camtschatica, the greatest effect of regeneration out of other explants was also achieved for hypocotyls, but condi-
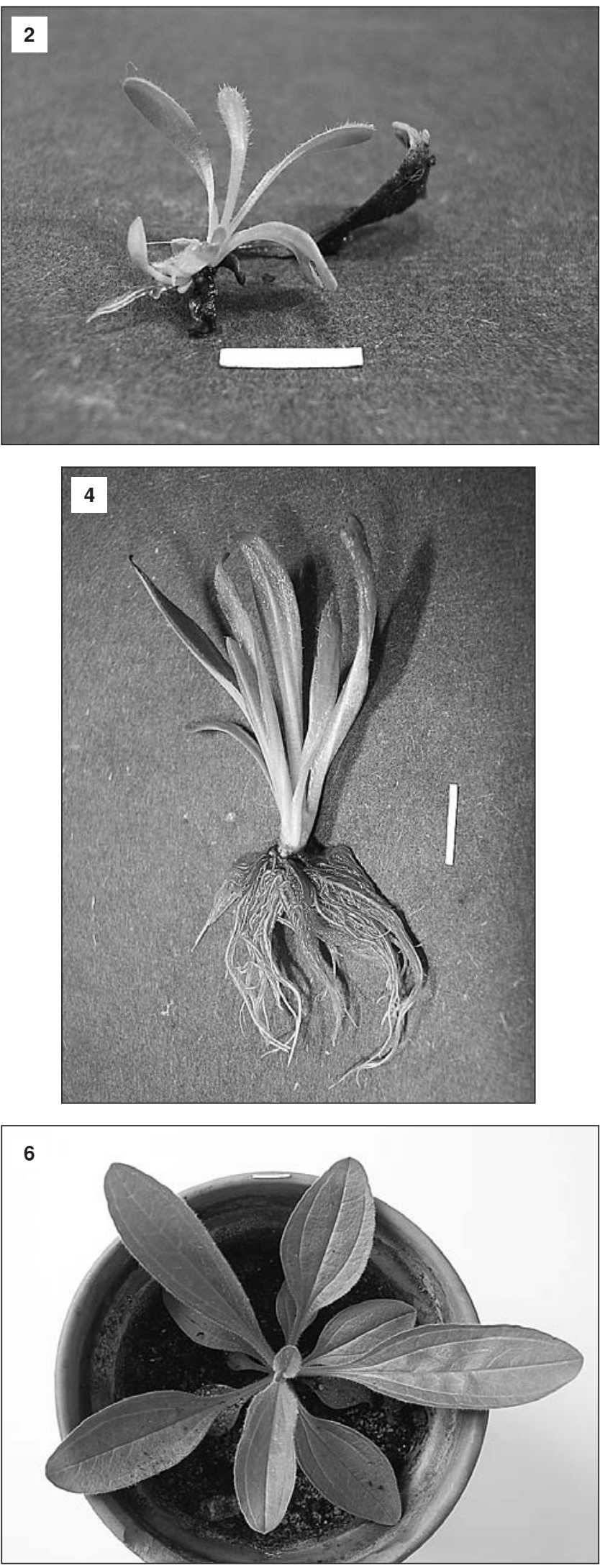
TABLE 3. Effect of medium with various cytokinins and $0.6 \mu \mathrm{M}$ IAA on shoot micropropagation on various explants of Plantago camtschatica.

\begin{tabular}{|c|c|c|c|c|c|c|}
\hline $\begin{array}{l}\text { Kind } \\
\text { of explants }\end{array}$ & Cytokinin & $\begin{array}{c}\% \text { of explants } \\
\text { with buds and shoots }\end{array}$ & $\begin{array}{c}\text { MR of buds } \\
\text { and shoots } \\
\pm \mathrm{SE}\end{array}$ & $\begin{array}{l}\% \text { of abnormal } \\
\text { buds and shoots }\end{array}$ & $\begin{array}{l}\text { Mean shoot length } \\
\quad(\mathrm{cm}) \pm \mathrm{SE}\end{array}$ & $\begin{array}{c}\% \text { of shoots } \\
\text { with roots }\end{array}$ \\
\hline Root & $\begin{array}{l}\text { BA } \\
\text { KIN } \\
\text { ZEA }\end{array}$ & $\begin{array}{c}95.0 \\
60.0 \\
100\end{array}$ & $\begin{array}{c}7.2 \pm 1.1 \\
6.9 \pm 1.0 \\
12.7 \pm 1.1\end{array}$ & $\begin{array}{l}16.8 \\
10.8 \\
30.6\end{array}$ & $\begin{array}{l}2.3 \pm 0.2 \\
2.2 \pm 0.1 \\
2.6 \pm 0.1\end{array}$ & $\begin{array}{l}10.0 \\
29.9 \\
16.7\end{array}$ \\
\hline Hypocotyl & $\begin{array}{c}\text { BA } \\
\text { KIN } \\
\text { ZEA }\end{array}$ & $\begin{array}{c}90.0 \\
90.0 \\
100\end{array}$ & $\begin{array}{c}13.2 \pm 1.8 \\
8.7 \pm 1.2 \\
12.6 \pm 1.3\end{array}$ & $\begin{array}{l}27.4 \\
11.5 \\
16.7\end{array}$ & $\begin{array}{l}1.9 \pm 0.1 \\
2.0 \pm 0.1 \\
1.9 \pm 0.1\end{array}$ & $\begin{array}{l}21.5 \\
37.3 \\
29.8\end{array}$ \\
\hline Cotyledo & $\begin{array}{l}\text { BA } \\
\text { KIN } \\
\text { ZEA }\end{array}$ & $\begin{array}{l}70.0 \\
80.0 \\
90.0\end{array}$ & $\begin{array}{l}5.3 \pm 0.7 \\
8.1 \pm 1.5 \\
8.2 \pm 1.6\end{array}$ & $\begin{array}{c}5.4 \\
12.3 \\
14.3\end{array}$ & $\begin{array}{l}2.3 \pm 0.4 \\
1.6 \pm 0.1 \\
1.7 \pm 0.1\end{array}$ & $\begin{array}{l}59.1 \\
61.7 \\
36.9\end{array}$ \\
\hline Leaf & $\begin{array}{l}\text { BA } \\
\text { KIN } \\
\text { ZEA }\end{array}$ & $\begin{array}{l}81.8 \\
70.0 \\
80.0\end{array}$ & $\begin{array}{l}5.2 \pm 1.3 \\
6.7 \pm 1.4 \\
6.5 \pm 1.4\end{array}$ & $\begin{array}{l}25.5 \\
40.4 \\
15.4\end{array}$ & $\begin{array}{l}2.4 \pm 0.3 \\
2.1 \pm 0.1 \\
2.1 \pm 0.2\end{array}$ & $\begin{array}{l}43.8 \\
66.7 \\
17.2\end{array}$ \\
\hline
\end{tabular}

SE - standard error of the mean

Concentration of the cytokinin: $8.9 \mu \mathrm{M}$ BA, $9.3 \mu \mathrm{M}$ KIN, $9.1 \mu \mathrm{M}$ ZEA

For each treatment about 10-20 explants were used.

In our experiments only direct organogenesis occurred, analogous with the case of $P$. lanceolata regenerated by Budzianowska et al. (2004) from segments of leaves and roots on MS with $11.42 \mu \mathrm{M}$ IAA and $9.29 \mu \mathrm{M}$ KIN. By indirect organogenesis, $P$. afra from leaves (Sarihan et al. 2005) on MS containing $0.91 \mu \mathrm{M}$ TDZ and $0.98 \mu \mathrm{M}$ IBA and $P$. ovata from hypocotyls on MS enriched with 4.5 $\mu \mathrm{M}$ 2,4-D and 4.6 $\mu \mathrm{M}$ KIN (Wakhlu and Barna 1989) were regenerated. Whereas $P$. asiatica from hypocotyls was regenerated by direct and also indirect organogenesis (Makowczyńska 2006).

According to our research results it is possible to micropropagate $P$. camtschatica from different explants, but hypocotyls have been found to be the most effective for induction of shoot formation.

On the part of shoots obtained as a result of organogenesis during 6-week culture adventitious roots developed spontaneously (Fig. 5). The cytokinin KIN was found to be the most effective for induction of the spontaneous root organogenesis during shoot regeneration. The greatest percentage of shoots with adventitious roots was observed for leaves culture with KIN. Rooting of the shoots during the shoot micropropagation allows to omit the stage of rooting after the shoot micropropagation.

The part of buds and shoots were abnormal (less or more hyperhydrous or deformed). The abnormal behaviour can be attributed to the excess of growth regulators in the explants. These abnormal shoots were rejected and only well-developed shoots were chosen for rooting and acclimatisation.

The rooting of shoots (without roots after 6-week culture) (Table 4, Figs 3 and 4)

The rooting was most effective on shoots cultured on MS without auxin or on MS with $0.5 \mu \mathrm{M}$ NAA. No callusing or browning was observed during root formation.

\section{Acclimatisation (Fig. 6)}

For two months of the acclimatisation in flower pots only $14 \%$ plants regenerated from seedling tips and $27 \%$ plants regenerated from other seedling explants survived.

The plants obtained as a result of micropropagation were not phenotypically changed (visual observations).

TABLE 4. Effect of medium with various kinds of auxins on rooting of Plantago camtschatica shoots.

MS suplemented

\begin{tabular}{|c|c|c|c|c|}
\hline $\begin{array}{l}\text { Concentration } \\
\text { of auxin } \\
(\mu \mathrm{M})\end{array}$ & Auxin & $\begin{array}{c}\% \text { shoots } \\
\text { with roots }\end{array}$ & $\begin{array}{c}\text { Mean number } \\
\text { of roots per explant } \\
\pm \mathrm{SE}\end{array}$ & $\begin{array}{l}\text { Mean root length } \\
\text { (cm) } \pm \mathrm{SE}\end{array}$ \\
\hline 0.6 & IAA & 75.0 & $3.6 \pm 0.6$ & $2.5 \pm 0.2$ \\
\hline 0.5 & IBA & 75.0 & $3.9 \pm 0.2$ & $3.9 \pm 0.2$ \\
\hline 0.5 & NAA & 89.7 & $5.5 \pm 0.6$ & $1.1 \pm 0.1$ \\
\hline 2.8 & IAA & 69.0 & $2.5 \pm 0.3$ & $1.9 \pm 0.1$ \\
\hline 2.5 & IBA & 54.8 & $3.6 \pm 0.5$ & $0.8 \pm 0.1$ \\
\hline 2.7 & NAA & 67.7 & $8.1 \pm 0.9$ & $0.7 \pm 0.0$ \\
\hline 0 & Control & 90.0 & $2.6 \pm 0.2$ & $3.9 \pm 0.2$ \\
\hline
\end{tabular}

SE - standard error of the mean

For each treatment about 29-31 explants were used. 
The in vitro cultures may be applied for the propagation of the $P$. camtschatica species which do not grow in Poland.

Obtained by us in vitro cultures of $P$. camtschatica can provide plant material for phytochemical analysis. Since regenerated shoots of this plant may contain such important secondary metabolities as iridoid and phenylpropanoid glucosides, the in vitro cultures could be important as the source of these substances.

\section{ACKNOWLEDGEMENTS}

The authors thank Mgr M. Baranowska for technical assistance.

The work is financed by the fund from the Medical University of Łódź, No. 502-13-486.

\section{LITERATURE CITED}

BAROT S.M., JASRAI Y.T., METHA A.R. 1994. In vitro organogenesis from leaf explants in Plantago ovata. In: Advances in plant tissue culture in India. Pramod Tandon (ed.). Pragati Prakashan, Meerut, pp. 82-86.

BRIMER L. 1988. Production of plantamajoside and verbascoside in suspension cell cultures of Plantago major spp. In Vitro Cell Develop Biol. 39th Annual Meeting of the Tissue Culture Association, Las Vegas 1988, 24(3): 36A.

BUDZIANOWSKA A., SKRZYPCZAK L., BUDZIANOWSKI J. 2004. Phenylethanoid glucosides from in vitro propagated plants and callus cultures of Plantago lanceolata. Planta Med. 70: 834-840.

CHANG I.D., LOCY R.D. 1996. In vitro regeneration of plants of the halophyte Plantago maritima L., from primary explants and callus cultures. In Vitro Cell Develop. Biol., Program Issue World Congress on In Vitro Biology, San Francisco 1996, 32(3): 91A.

CHOWDHURY A.R., KUNDU S., SEN RAYCHAUDHURI S. 1996. Regeneration of Plantago ovata Forssk through somatic embryogenesis. Cytobios 85: 255-261.

FONS F., TOUSCH D., RAPIOR S., GUEIFFIER A., ROUSSEL J.L., GARGADENNEC A., ANDARY C. 1999. Phenolic profiles of untransformated and hairy root cultures of Plantago lanceolata. Plant Physiol. Biochem. 37(4): 291-296.

KHAWAR K.M., SARIHAN E.O., SEVIMAY C.S., ÇÖÇÜ S., PARMAKSIZ I., URANBEY S., IPEK A., KAYA M.D., SANCAK C., ÖZCAN S. 2005. Adventitious shoot regeneration and micropropagation of Plantago lanceolata L. Period. Biol. 107: 113-116.

KUNVÁRI M., PÁSKA C., LÁSZLÓ M., GYURJÁN I. 1999. Effect of different media parameters on the growth and verbascoside production on Plantago media L. tissue culture In: 47th Annual Congress of the Society for Medical Plant Research, Amsterdam 26-30 July 1999.
LEE W.T. 1996. Lineamenta Florae Koreae, Academy Press, Seul.

MAKOWCZYŃSKA J. 2006. Mikrorozmnażanie Plantago asiatica L. Badania histologiczne i cytologiczne. Ph.D. dissertation. Medical University of Łódź. (in Polish)

MAKOWCZYŃSKA J., ANDRZEJEWSKA-GOLEC E. 2003. Micropropagation of Plantago asiatica L. through culture of shoot-tips. Acta Soc. Bot. Pol. 72(3): 191-194.

MAKOWCZYŃSKA J., ANDRZEJEWSKA-GOLEC E. 2007. Micropropagation of Plantago maritima L. In: 3rd CountryCongress of Biotechnology, Agricultural University, Poznań, 9-12 September 2007.

MAKOWCZYŃSKA J., ANDRZEJEWSKA-GOLEC E., SLIWINSKA E. 2008. Nuclear DNA content in different plant materials of Plantago asiatica L. cultured in vitro. Plant Cell Tiss. Org. Cult. 94: 65-71.

MEDEROS S., MARTIN C., NAVARRO E., AYUSO M.J. 1997/98. Micropropagation of a medicinal plant, Plantago major L. Biol. Plant. 40(3): 465-468.

NISHIBE S., TAMAYAMA Y., SASAHARA M., ANDARY C. 1995. A phenylethanoid glycoside from Plantago asiatica. Phytochemistry 38(3): 741-743.

PILGER R. 1937. Plantaginaceae. In: Das Pflanzenreich. Regni vegetabilis conspectus. Engler A., Diels L. (eds). Engelman, Leipzig, Vol. 4, pp. 1-466.

PRAMANIK S., CHAKRABORTY S., SEN RAYCHAUDHURI S. 1995. In vitro clonal propagation and characterization of clonal regenerants of Plantago ovata Forssk by isozyme analysis. Cytobios 82: 123-130.

PRAMANIK S., SEN RAYCHAUDHURI S., CHAKRABORTY S. 1996. Changes in esterase and superoxide dismutase isozymes during in vitro morphogenesis in Plantago ovata Forssk. Plant Cell Tiss. Org. Cult. 44: 123-127.

RØNSTED N., FRANZYK H., MØLGAARD P., JAROSZEWSKI J.W., JENSEN S.R. 2003. Chemotaxonomy and evolution of Plantago L. Plant Syst. Evol. 242: 63-82.

SARIHAN E.O., KHAWAR M.D., ÖZCAN S. 2005. Profilic adventitious shoot regeneration from black psyllium (Plantago afra L.). Gen. Appl. Plant Physiol. 31(1-2): 81-87.

TU Y. 1996 Tissue culture of Asiatic plantain (Plantago asiatica). Zhongcaoyao 27: 296-298. (in Chinese with English summary)

WAKHLU A.K., BARNA K.S. 1989. Callus initiation, growth and plant regeneration in Plantago ovata Forsk. cv. GI-2. Plant Cell Tiss. Org. Cult. 17: 235-241.

YAMAZAKI T. 1993. Plantaginaceae. In: Flora of Japan. Iwatsuki K., Yamazaki T., Boufford D.E., Ohba H. (eds). Kodansha LTD. Tokyo, Vol. 3a, p. 384.

YING J., SASAHARA M., NISHIBE S., YAN CHANG LU, TANAKA T. 1993. Studies on constituents of plantaginis herba. 4. On phenylethanoid glycosides of Plantago camtschatica. Shoyakugaku Zasshi (Japan. J. Pharmacogn.) 47(3): 330-333. 